\title{
Optimization of Cellulase Production from Newly Isolated Bacillus sp. Y3
}

Yogita Lugani ${ }^{1,2}$, Rajesh Singla ${ }^{2}$ and Balwinder Singh Sooch ${ }^{1 *}$

${ }^{1}$ Department of Biotechnology, Punjabi University, Patiala, Punjab, India

${ }^{2}$ Dolphin (PG) College of Life Sciences, Chunni Kalan, Punjab, India

\begin{abstract}
Cellulose, a major constituent of plant cell wall, is the most abundant biological polymer on earth. The use of various cellulolytic microorganisms for the bioconversion of cellulose into value added products has attracted a worldwide attention. Hence the present work was aimed to isolate new cellulase producing microorganisms and further to investigate the effect of nutritional and process parameters on cellulase production from selected isolated culture. Out of 20 cellulase producing bacterial strains isolated during the study, Y3 isolate was found to be best for the production of cellulase enzyme. This isolate was then characterized for its morphological and biochemical characters and identified as Bacillus sp. Y3. The effect of different parameters like carbon sources, nitrogen sources, temperature, $\mathrm{pH}$, inoculum concentration and incubation time was monitored with selected strain for cellulase production. The maximum FPase and CMCase activity of Bacillus sp. Y3 was $6.84 \mathrm{IU} / \mathrm{mL}$ and $7.82 \mathrm{IU} /$ $\mathrm{mL}$, respectively, when the basal media of $\mathrm{pH} 7$ containing CMC $(1 \%, \mathrm{w} / \mathrm{v})$ and peptone $(1 \%, \mathrm{w} / \mathrm{v})$ was inoculated with $2 \%(\mathrm{v} / \mathrm{v})$ inoculum and incubated at $37^{\circ} \mathrm{C}$ for 96 hours at $120 \mathrm{rpm}$. The FPase $(6.84 \mathrm{IU} / \mathrm{mL})$ and CMCase activity $(7.82 \mathrm{IU} / \mathrm{mL})$ obtained after optimization was much higher than FPase $(1.97 \mathrm{IU} / \mathrm{mL})$ and CMCase activity $(2.48 \mathrm{IU} /$ $\mathrm{mL}$ ) before optimization.
\end{abstract}

Keywords: Isolation; Exoglucanase; Endoglucanase; Bacillus; Cellulase; Cellulose

\section{Introduction}

Cellulose, a major constituent of plant cell wall, is the most abundant biological polymer on earth. It is the primary product of photosynthesis in terrestrial ecosystem [1]. Cellulose $\left(\mathrm{C}_{6} \mathrm{H}_{10} \mathrm{O}_{5}\right)_{n}$ is found in crystalline form with close packing to form a compact structure and consist of thousands of glucose molecules, which are linked together by $\beta$-1,4-glycosidic linkage in a linear fashion. Major focus has been given to the development of sustainable systems for effective utilization of this cellulosic waste material for the economical cellulase production. The use of various cellulolytic microorganisms under aerobic and thermophilic conditions for the bioconversion of cellulose into value added products like sugar and alcohol has attracted a worldwide attention [2].

Cellulose is commonly degraded by cellulase enzyme which consists of three major components i.e., endoglucanases (EC 3.2.1.4), exoglucanases (EC 3.2.1.74) and $\beta$-glucosidases (EC 3.2.1.21). Both the structures of cellulose i.e., crystalline as well as paracrystalline are readily hydrolyzed by cellulases. This enzyme is mainly produced by several bacterial and fungal cultures [3]. Members of domain Bacteria have gained intense importance for development of commercial process of cellulose degradation because of its high growth rate, wide genetic variability, adaptability and high amendability to genetic manipulation [1]. However, until recently, the study on bacterial cellulases lagged behind the fungal ones due to its potential to hydrolyze only synthetic form of carboxymethyl cellulose [4]. The use of various agricultural wastes like peanut shell, banana peel, okara, bagasse, corncob, sawdust, water hyacinth, sorghum straw and rice straw, which could result in serious environmental pollution, provides a low cost feedstock of cellulose for the production of cellulase using solid state fermentation [5]. There are various factors like inoculum size, $\mathrm{pH}$ value, temperature, presence of inducers, aeration and growth time etc. which affect the yield of cellulase.

Extensive basic and applied research on cellulases revealed the commercial significance and industrial applicability of this enzyme. Cellulase has a wide range of applications in a variety of sectors such as food, paper/pulp, pharmaceuticals, textiles, alcoholic beverages, malting and brewing, starch processing, biofuel production and leather etc. [2]. Keeping in view these facts about cellulase and its usability in industrial sectors, the present study was focused to isolate and screen cellulolytic bacteria for the production of cellulase and further to optimize different nutritional and process parameters for maximum cellulase production from selected isolated culture.

\section{Materials and Methods}

\section{Collection of soil samples}

Different soil and cow dung samples were collected from different locations of Punjab and Himachal Pradesh by using pre-sterilized petri dishes for the isolation of cellulose degrading bacteria. The samples were dried, powdered and cleared of impurities by sieving and then stored at $4^{\circ} \mathrm{C}$ until further use.

\section{Enrichment, isolation and screening of cellulase producing bacteria}

For the enrichment of collected soil and cow dung samples for the isolation of cellulase producing bacteria, the collected samples were added in a basal media containing $\left(\mathrm{NH}_{4}\right)_{2} \mathrm{SO}_{4}(0.5 \mathrm{~g} / \mathrm{L}), \mathrm{KH}_{2} \mathrm{PO}_{4}(10$ $\mathrm{g} / \mathrm{L}), \mathrm{K}_{2} \mathrm{HPO}_{4}(5 \mathrm{~g} / \mathrm{L}), \mathrm{MgSO}_{4}(0.1 \mathrm{~g} / \mathrm{L}), \mathrm{NaCl}(0.2 \mathrm{~g} / \mathrm{L})$, yeast extract $(10$ $\mathrm{g} / \mathrm{L})$ and carboxymethylcellulose $(3 \mathrm{~g} / \mathrm{L})$ in separate flasks and incubated at $37^{\circ} \mathrm{C}$ for 48 hours [6]. The cellulase producing cultures were then

*Corresponding author: Balwinder Singh Sooch, Assistant Professor, Enzyme Biotechnology Laboratory, Department of Biotechnology, Punjabi University, Patiala, Punjab-147002, India, Tel: +91-0175-304-6263; Fax: +91-0175-228-3063; E-mail: soochb@yahoo.com

Received September 27, 2015; Accepted November 26, 2015; Published November 30,2015

Citation: Lugani Y, Singla R, Sooch BS (2015) Optimization of Cellulase Production from Newly Isolated Bacillus sp. Y3. J Bioprocess Biotech 5: 264. doi:10.4172/2155 9821.1000264

Copyright: ( 2015 Lugani Y, et al. This is an open-access article distributed under the terms of the Creative Commons Attribution License, which permits unrestricted use, distribution, and reproduction in any medium, provided the original author and source are credited. 
isolated using serial dilution, plate pouring and plate streaking methods by primary screening on CMC (carboxymethylcellulose) enriched nutrient agar media containing nutrient agar $(28 \mathrm{~g} / \mathrm{L})$ and CMC $(10$ $\mathrm{g} / \mathrm{L}$ ) with $\mathrm{pH}$ 7. These plates were incubated at $37^{\circ} \mathrm{C}$ for 48 hours. The cellulase producing colonies of bacterial cultures were then selected by screening on CMC agar plates as well as Congo red agar plates by the method of Teather and Wood [7].

Apart from the qualitative test, the quantitative test for cellulase activity was also performed by cultivating the bacterial culture on the basal media with $\mathrm{pH} 7.0$ and incubated at $37^{\circ} \mathrm{C}$ for 48 hours. The isolate which showed maximum cellulase producing ability both by qualitative (zone of inhibition) as well as quantitative (amount of glucose released) method was selected for further study.

\section{Maintenance of isolates}

The best bacterial isolate with maximum cellulase production was further maintained after obtaining pure culture on nutrient agar slants containing peptone $(5.0 \mathrm{~g} / \mathrm{L})$, beef extract $(3.0 \mathrm{~g} / \mathrm{L})$, agar $(20 \mathrm{~g} / \mathrm{L})$. These slants were stored at $4^{\circ} \mathrm{C}$ until further use. The selected isolate i.e., Y3 was maintained on the nutrient agar slants by sub culturing at regular time intervals.

\section{Identification of isolate by morphological and biochemical characterization}

The best isolate $\mathrm{Y} 3$ with maximum cellulase production was tested for morphological and biochemical characteristics for its identification.

Morphological characterization: The overnight grown bacterial suspension of selected isolate $\mathrm{Y} 3$ was used for the morphological characterization by Gram staining [8] and other colony characteristics like configuration, margin, texture and color using standard protocols.

Biochemical characterization: Different biochemical tests like catalase, Indole production, starch hydrolysis, urease, methyl red and voges proskauer (MR-VP), gelatin hydrolysis and sugar fermentation were carried out for the further characterization of selected isolate Y3 using standard protocols [9].

Optimization of culture conditions for cellulase production: The optimization of medium and process parameters like carbon source, nitrogen source, temperature, $\mathrm{pH}$, inoculum size and incubation time etc. were carried out on the basis of stepwise modifications for governing the cellulase production by selected and identified bacterial isolate i.e. Bacillus sp. Y3.

Effect of carbon sources: The effect of different substrates as carbon source like wheat bran, rice bran, glucose, lactose and CMC were tested for their effect on enzyme activity by Bacillus sp. Y3. Each substrate was added to a concentration of $1 \%(\mathrm{w} / \mathrm{v})$ in the basal media containing $\left(\mathrm{NH}_{4}\right)_{2} \mathrm{SO}_{4}(0.5 \mathrm{~g} / \mathrm{L}), \mathrm{KH}_{2} \mathrm{PO}_{4}(10 \mathrm{~g} / \mathrm{L}), \mathrm{K}_{2} \mathrm{HPO}_{4}(5 \mathrm{~g} / \mathrm{L})$, $\mathrm{MgSO}_{4}(0.1 \mathrm{~g} / \mathrm{L}), \mathrm{NaCl}(0.2 \mathrm{~g} / \mathrm{L})$, yeast extract $(10 \mathrm{~g} / \mathrm{L})$ with $\mathrm{pH}$ 7. All the flasks containing different substrates were incubated at $37^{\circ} \mathrm{C}$ for 72 hours at $120 \mathrm{rpm}$. The culture broth was centrifuged at $5000 \mathrm{rpm}$ for 20 minutes at $4^{\circ} \mathrm{C}$ and the supernatant served as the crude enzyme source. The cellulase activity was determined by FPase and CMCase method [10]. The effect of different concentrations $(0.5 \%, 1 \%, 1.5 \%, 2 \%, 2.5 \%$ $\mathrm{w} / \mathrm{v}$ ) of selected carbon source was also studied to evaluate its effect on enzyme activity.

Effect of nitrogen sources: The media was supplemented with different organic and inorganic nitrogen sources like peptone, yeast extract, $\left(\mathrm{NH}_{4}\right)_{2} \mathrm{SO}_{4}, \mathrm{NH}_{4} \mathrm{Cl}$ and $\mathrm{NaNO}_{3}$, each with $1 \%(\mathrm{w} / \mathrm{v})$ concentration to investigate their effect on enzyme activity. The effect of different concentrations of selected nitrogen source $(0.5 \%, 1 \%$, $1.5 \%, 2 \%, 2.5 \%, \mathrm{w} / \mathrm{v}$ ) was also studied on the production of cellulase by Bacillus sp. Y3.

Effect of temperature: Temperature is an important factor in a bioprocess for the production of extracellular enzyme. For the selection of optimum temperature for cellulase production by Bacillus sp. Y3, the inoculated optimized media in separate flasks was incubated at different temperature $\left(20^{\circ} \mathrm{C}, 30^{\circ} \mathrm{C}, 37^{\circ} \mathrm{C}, 45^{\circ} \mathrm{C}, 55^{\circ} \mathrm{C}\right)$ for 72 hours.

Effect of pH: $\mathrm{pH}$ is another factor affecting the microbial growth as well as enzyme production. Therefore, the experiments were carried out by using the optimized media of different $\mathrm{pH}$ values $(4.0,5.0,6.0$, $7.0,8.0)$ to study their effect on cellulase production by Bacillus sp. Y3

Effect of inoculum concentration: The effect of different inoculum concentrations $(0.5 \%, 1 \%, 2 \%, 3 \%, 4 \%, \mathrm{v} / \mathrm{v})$ of selected $\mathrm{Y} 3$ bacterial isolate i.e., Bacillus sp. Y3 were also monitored on cellulase activity after 72 hours of incubation.

Effect of incubation time: The effect of incubation time was observed on cellulase activity produced by Bacillus sp. Y3 by incubating the optimized media at $37^{\circ} \mathrm{C}$ for different time intervals $(24,48,72,96$, $120,144,168$ hours)

\section{Enzyme assay}

Carboxymethylcellulase assay: CMCase activity was assayed by using $1 \%(\mathrm{w} / \mathrm{v})$ solution of carboxymethylcellulose (CMC) as substrate in $0.05 \mathrm{M}$ citrate buffer $(\mathrm{pH} 4.8)$ as described by Mandels and Weber [10]. The reaction mixture contained $1 \mathrm{~mL}$ citrate buffer, $0.5 \mathrm{~mL}$ of substrate solution and $0.5 \mathrm{~mL}$ of suitably diluted enzyme solution and incubated at $50^{\circ} \mathrm{C}$ for 30 minutes. The amount of reducing sugar released by the hydrolysis of CMC was measured at $540 \mathrm{~nm}$ by the DNS method [11] using glucose as standard. One unit of CMCase activity was expressed as $1 \mu \mathrm{mol}$ of glucose liberated per $\mathrm{mL}$ per minute.

Filter paper assay: The method of FPase is similar to the CMCase assay method, but the substrate was Whatman No.1 filter paper strip (1 $\times 6 \mathrm{~cm}$ ) which was soaked in $1 \mathrm{~mL}$ of $0.05 \mathrm{M}$ sodium citrate $(\mathrm{pH} 4.8)$ as described by the method of Mandels and Weber [10]. The reaction mixture contained $1 \mathrm{~mL}$ citrate buffer, filter paper strip and $0.5 \mathrm{~mL}$ of suitably diluted enzyme solution and it was left at $50^{\circ} \mathrm{C}$ for 1 hour. The amount of reducing sugars released from the filter paper strip during growth was determined by DNS method using glucose as the standard [11]. One unit of FPase activity was determined as $1 \mu \mathrm{mol}$ of glucose liberated per $\mathrm{mL}$ per minute.

\section{Results and Discussion}

\section{Isolation and screening of cellulase producing bacteria}

A total number of 20 isolates were obtained from the soil and cow dung samples collected from various locations. These isolates were screened for their cellulase producing ability using CMC as a source of carbon and Congo red dye as an indicator to check zone of inhibition, produced by the hydrolysis of cellulose. Only 16 isolates showed positive test for cellulase production on CMC agar plates containing Congo red dye. The best five isolates showing positive cellulase test with highest ratio of clear zone diameter to colony diameter on Congo red agar plates are shown in Table 1.

It is depicted from the Table 1 that maximum ratio of clear zone diameter to colony diameter $(9.75 \mathrm{~mm})$ was obtained with $\mathrm{Y} 3$ isolate on the plate containing $\mathrm{CMC}$ as carbon source and Congo red dye as 
indicator due to secretion of extracellular cellulase as shown in Figure 1A. The best $Y 3$ isolate was obtained from the cow dung sample because the diet of ruminants primarily consists of cellulosic matter and hence there is a rich assemblage of cellulolytic microorganisms in the rumen of ruminants [12]. For further quantitative estimation of cellulase activity, each isolate was grown separately in the enrichment media containing CMC $(1 \%, w / v)$ as discussed in previous section and cell free extract was analyzed for enzyme activity. The maximum FPase and CMCase activity of $1.97 \mathrm{IU} / \mathrm{mL}$ and $2.48 \mathrm{IU} / \mathrm{mL}$ respectively was found with Y3 isolate and these quantitative results of cellulase production were in accordance with the qualitative results.

Similar method was also used by some other workers for the selection of best cellulase producing bacteria on the basis of clear zone diameter [13-15]. The cellulase producing isolate Bacillus sp. SDF, isolated from the municipal waste have shown a zone of inhibition of $3.4 \mathrm{~mm}$ on Congo red plate with enzyme activity of $0.2514 \mathrm{IU} / \mathrm{mL}$ after 48 hours [13]. Cellulase producing Bacillus sp., isolated from soil and waste (molasses) of sugar industry, showed a zone of inhibition of $9.5 \mathrm{~mm}$ on Congo red plate with enzyme activity of $3.198 \mathrm{IU} / \mathrm{mL}$ [14]. However, a very large zone of inhibition of $26 \mathrm{~mm}$ with enzyme activity of $6.4 \mathrm{IU} / \mathrm{mL}$ was also recorded with Bacillus subtilis, isolated from cotton industry, Zirakpur [15].

\section{Identification of Y3 isolate}

The best bacterial isolate was identified on the basis of morphological and biochemical tests. White coloured, smooth, raised and circular colonies of selected isolate $\mathrm{Y} 3$ were obtained on $\mathrm{CMC}$ agar plate (Figure 1B). The results of Gram staining showed that the isolated bacteria belong to Gram positive bacilli with purple coloured rod shaped cells seen under the microscope. The isolate showed positive results for catalase, Indole production, citrate utilization, starch hydrolysis and gelatin hydrolysis, however, negative results were observed with urease production and MR-VP test. The sugar fermentation test was positive with sucrose, glucose, fructose and mannitol with both acid and gas formation, however, the test was negative with lactose. The results

Table 1: Top Five extracellular cellulase producing bacterial isolates with zone of inhibition on Congo red plates.

\begin{tabular}{|c|c|c|c|c|c|}
\hline $\begin{array}{c}\text { S } \\
\text { No }\end{array}$ & Sample & $\begin{array}{c}\text { Colony } \\
\text { code }\end{array}$ & $\begin{array}{c}\text { Clear zone } \\
\text { diameter } \\
\text { (mm) }\end{array}$ & $\begin{array}{c}\text { Colony } \\
\text { diameter } \\
\text { (mm) }\end{array}$ & $\begin{array}{c}\text { Ratio of clear zone } \\
\text { to colony diameter } \\
\text { (mm) }\end{array}$ \\
\hline 1. & Timber mill soil & $\mathrm{Y} 1$ & $1.33 \pm 0.02$ & $0.19 \pm 0.01$ & 7 \\
\hline 2. & Paddy straw soil & $\mathrm{Y} 2$ & $2.25 \pm 0.03$ & $0.25 \pm 0.02$ & 9 \\
\hline 3. & Cow dung soil & $\mathrm{Y} 3$ & $2.34 \pm 0.03$ & $0.24 \pm 0.02$ & 9.75 \\
\hline 4. & Sugar mill soil & $\mathrm{Y} 4$ & $1.40 \pm 0.01$ & $0.20 \pm 0.02$ & 7 \\
\hline
\end{tabular}
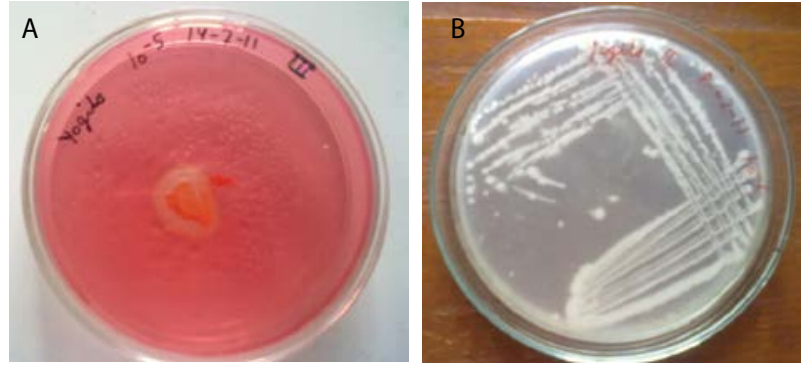

Figure 1: $A$ : Zone of clearance by $Y 3$ isolate showing production of cellulase. B: Isolated colony of Bacillus sp. Y3 showing its colony morphological characteristics. of morphological and biochemical tests are given in Table 2. It was concluded from the above results that the isolate is closely related to genus Bacillus sp. as evident from its morphological and biochemical tests on the basis of Bergey's Manual of Systematic bacteriology [9]. From the morphological and biochemical characteristics, the best selected cellulase producing isolate was named as Bacillus sp. Y3.

\section{Optimization of culture conditions}

The best cellulase producing isolate was identified as Bacillus sp. Y3. The media and culture conditions like substrate/carbon source, nitrogen source, temperature, $\mathrm{pH}$, inoculum size and incubation time were further optimized for the maximum production of cellulase in a stepwise manner. The optimization of media is an important parameter for the development of fermentation technology because a cost effective media results in the reduction of cost of enzyme.

\section{Effect of carbon sources}

The best cellulolytic isolate Bacillus sp. Y3 was allowed to grow at $37^{\circ} \mathrm{C}$ for 72 hours in basal media of $\mathrm{pH} 7$ containing $\left(\mathrm{NH}_{4}\right)_{2} \mathrm{SO}_{4}$ $(0.5 \mathrm{~g} / \mathrm{L}), \mathrm{KH}_{2} \mathrm{PO}_{4}(10 \mathrm{~g} / \mathrm{L}), \mathrm{K}_{2} \mathrm{HPO}_{4}(5 \mathrm{~g} / \mathrm{L}), \mathrm{MgSO}_{4}(0.1 \mathrm{~g} / \mathrm{L}), \mathrm{NaCl}$ $(0.2 \mathrm{~g} / \mathrm{L})$, yeast extract $(10 \mathrm{~g} / \mathrm{L})$ of $\mathrm{pH} 7$ with combination of different carbon sources like wheat bran, rice bran, glucose, lactose and CMC (each with $1 \%(\mathrm{w} / \mathrm{v})$ concentration) to estimate their effect on cellulase production. The maximum FPase activity $(3.74 \mathrm{IU} / \mathrm{mL})$ and CMCase activity $(4.49 \mathrm{IU} / \mathrm{mL})$ was found when medium was supplemented with CMC (Figure 2). Hence it can be concluded that that cellulase is an inducible enzyme, whose production depends upon the presence of substrate which also acts as its inducer.

\section{Effect of different concentrations of CMC}

The best carbon source with maximum cellulase production from Bacillus sp. Y3 was found to be CMC at a concentration of $1 \%(\mathrm{w} / \mathrm{v})$. Therefore to analyze the effect of different concentrations of CMC on

Table 2: Morphological and biochemical characteristics of $Y 3$ isolate.

\begin{tabular}{|c|c|c|c|}
\hline S No & Morphological Tests & Observation & Result \\
\hline 1. & Gram Staining & $\begin{array}{l}\text { Purple coloured rod shaped } \\
\text { cells }\end{array}$ & +ve bacilli \\
\hline 2. & Colony morphology & $\begin{array}{l}\text { Single celled white coloured, } \\
\text { smooth, raised, circular with } \\
\text { entire margin colonies on } \\
\text { CMC agar plate }\end{array}$ & $\begin{array}{c}\text { Characteristics of } \\
\text { colony resemble } \\
\text { with growth of } \\
\text { Bacillus sp. }\end{array}$ \\
\hline S No & Biochemical Tests & Observation & Result \\
\hline 1. & Catalase & Slight Effervescence & $+v e$ \\
\hline 2. & Citrate utilization & Blue colour & $+\mathrm{ve}$ \\
\hline 3. & Indole production & Cherry red colour & $+\mathrm{ve}$ \\
\hline 5. & Starch hydrolysis & Clear zone & +ve \\
\hline 6. & Urease production & No colour change & -ve \\
\hline 7. & Methyl red & No colour change & -ve \\
\hline 8. & Voges proskauer & No colour change & -ve \\
\hline 9. & Gelatin Hydrolysis & Liquefaction & $+v e$ \\
\hline 10. & \multicolumn{3}{|c|}{ Sugar fermentation } \\
\hline (i) & Sucrose fermentation & $\begin{array}{l}\text { Red to yellow colour, Gas } \\
\text { formation }\end{array}$ & +ve \\
\hline (ii) & Lactose fermentation & $\begin{array}{l}\text { No change in colour, Gas } \\
\text { formation }\end{array}$ & -ve \\
\hline (iii) & Glucose fermentation & $\begin{array}{l}\text { Red to yellow colour, Gas } \\
\text { formation }\end{array}$ & +ve \\
\hline (iv) & Fructose fermentation & $\begin{array}{l}\text { Red to yellow colour, Gas } \\
\text { formation }\end{array}$ & +ve \\
\hline (v) & Mannitol Fermentation & $\begin{array}{l}\text { Red to yellow colour, Gas } \\
\text { formation }\end{array}$ & $+v e$ \\
\hline
\end{tabular}


cellulase production by the isolate, different concentrations of CMC $(0.5 \%, 1 \%, 1.5 \%, 2 \%, 2.5 \%, \mathrm{w} / \mathrm{v})$ were used in the media. The maximum cellulase production with both FPase and CMCase activity of 3.78 and $4.52 \mathrm{IU} / \mathrm{mL}$, respectively, was observed with $1 \%(\mathrm{w} / \mathrm{v})$ concentration of CMC (Figure 3).

Similar observations were also made by some other workers in the past. The maximum enzyme activity of $3.028 \mu \mathrm{g} / \mathrm{mg} / \mathrm{min}$ was achieved from Bacillus sp. when CMC was utilized as carbon source by Das et al. [12]. Sohair et al. [16] showed similar results with maximum cellulase production from Bacillus sp. in basal medium supplemented with $\mathrm{CMC}$ as a substrate at $40^{\circ} \mathrm{C}$ after 72 hours of incubation. A very high cellulase production of $104.68 \mathrm{U} / \mathrm{mL}$ was also found from Bacillus $s p$. BSS3 in the optimized media containing $1 \%(\mathrm{w} / \mathrm{v}) \mathrm{CMC}$ at $150 \mathrm{rpm}$ and $37^{\circ} \mathrm{C}$ [17]. Recently, the maximum cellulase production has also been reported with Bacillus amyloliquefaciens SS35 by using 1.9\% CMC [18].

\section{Effect of nitrogen sources}

The effect of different nitrogen sources like peptone, yeast extract, $\left(\mathrm{NH}_{4}\right)_{2} \mathrm{SO}_{4}, \mathrm{NH}_{4} \mathrm{Cl}$ and $\mathrm{NaNO}_{3}$ each with $1 \%$ (w/v) concentration in media was observed on cellulase production after 72 hours of incubation. The maximum FPase and CMCase activity of 4.18 and 4.72 $\mathrm{IU} / \mathrm{mL}$, respectively, were found with peptone as shown in Figure 4. The presence of external nitrogen source is essential in the fermentation media during extracellular enzyme production for effective utilization of soluble carbohydrates. The use of organic nitrogen sources as compared to inorganic sources for maximum cellulase production was found to be more suitable for maximum cellulase production $[19,20]$.

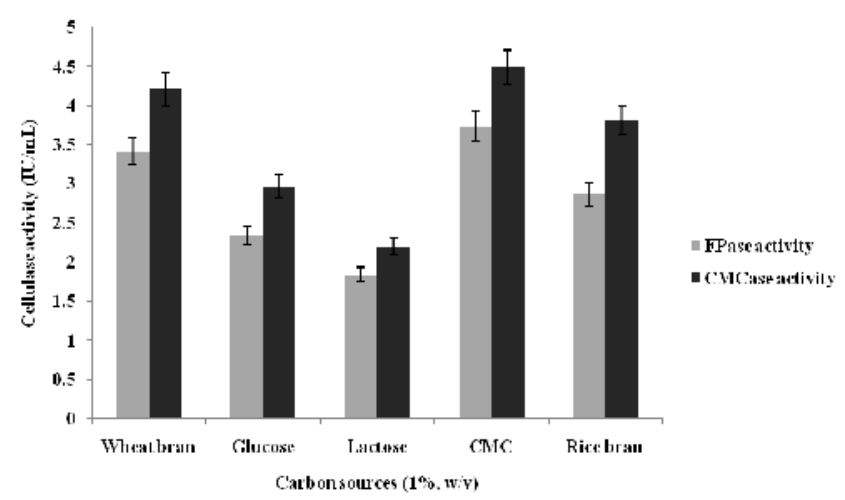

Figure 2: Effect of carbon sources $(1 \%, w / v)$ on cellulase production by Bacillus sp. Y3.

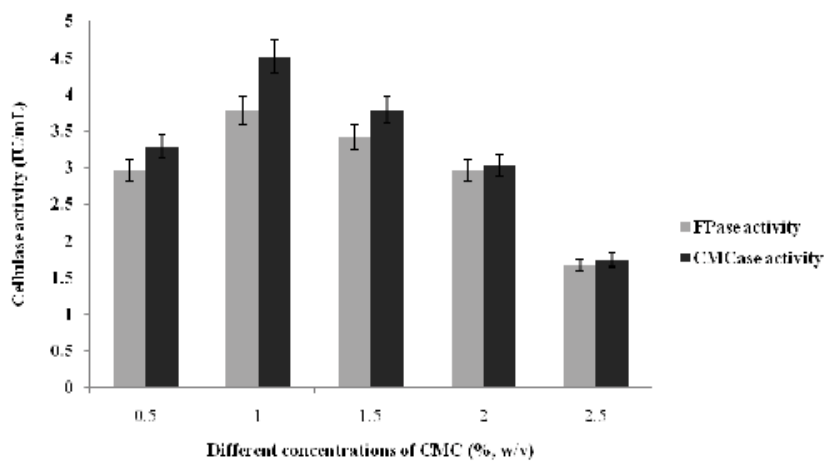

Figure 3: Effect of different concentrations of $\mathrm{CMC}$ on cellulase production by Bacillus sp. Y3.

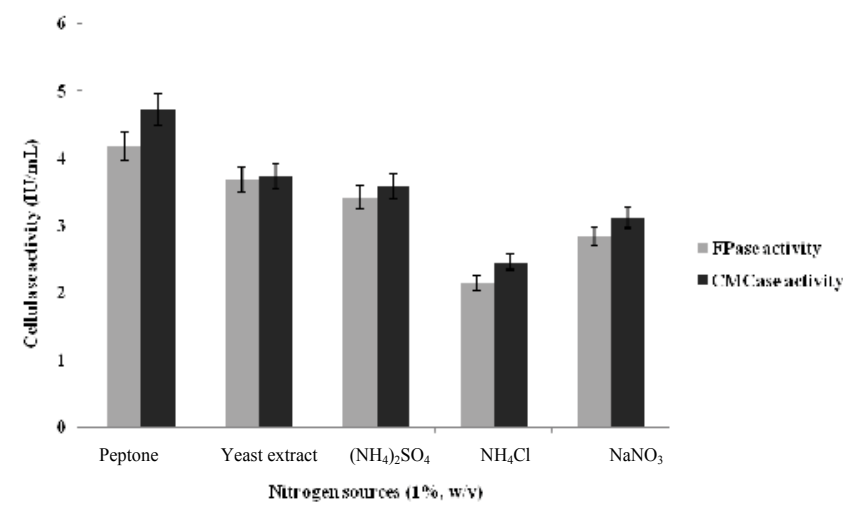

Figure 4: Effect of nitrogen sources on cellulase production by Bacillus sp. Y3.

\section{Effect of different concentrations of peptone}

Peptone was found to be best nitrogen source for maximum cellulase production from Bacillus sp. Y3, hence the effect of its different concentrations $(0.5 \%, 1 \%, 1.5 \%, 2 \%, 2.5 \%$, w/v) on cellulase production was investigated. The maximum cellulase production with both FPase and CMCase activity of 4.19 and $4.74 \mathrm{IU} / \mathrm{mL}$, respectively, was observed with $1 \%(\mathrm{w} / \mathrm{v})$ concentration of peptone, as shown in Figure 5.

Similarly the highest cellulase production was found with Bacillus subtilis by utilizing peptone as nitrogen source [21]. In a previous study, the maximum cellulase production by Bacillus sp. K1 at $1 \%$ (w/v) peptone concentration was reported by Paudel and Qin [22].

\section{Effect of temperature}

Temperature plays a crucial role in growth and physiology of microorganisms and its enzyme activity. Hence different temperatures i.e., $20^{\circ} \mathrm{C}, 30^{\circ} \mathrm{C}, 37^{\circ} \mathrm{C}, 45^{\circ} \mathrm{C}, 55^{\circ} \mathrm{C}$ were used for incubation of inoculated media containing Bacillus sp. Y3 cells for 72 hours to estimate their effect on enzyme activity. The maximum FPase activity and CMCase activity of 4.20 and $4.75 \mathrm{IU} / \mathrm{mL}$, respectively, was observed at $37^{\circ} \mathrm{C}$, which was slightly reduced to 4.17 and $4.37 \mathrm{IU} / \mathrm{mL}$, respectively, at $45^{\circ} \mathrm{C}$ (Figure 6). The reduction of enzyme activity was obtained with further increase in temperature. The increase in temperature, above the optimum values, results in loss of enzyme activity due to thermal denaturation of enzymes, hence low enzyme activity was observed above $45^{\circ} \mathrm{C}$.

Similar results of maximum cellulase production of $0.5851 \pm 0.006$ $\mathrm{IU} / \mathrm{mL}$ was achieved after 72 hours of incubation at $37^{\circ} \mathrm{C}$ from Bacillus pumilus EWBCM1 [23]. A very high cellulase production of $104.68 \mathrm{U} /$ $\mathrm{mL}$ was reported with Bacillus sp. $\mathrm{BSS} 3$ at $\mathrm{pH} 9,37^{\circ} \mathrm{C}$ with $1 \% \mathrm{CMC}$ [17].

\section{Effect of $\mathrm{pH}$}

The production media with different $\mathrm{pH}$ values $(4.0,5.0,6.0,7.0$, 8.0) was used for growth of Bacillus sp. Y3 to investigate its effect on cellulase production. The optimum $\mathrm{pH}$ for cellulase production was observed at $\mathrm{pH} 7$ with maximum FPase and CMCase activity of 4.22 and $4.76 \mathrm{IU} / \mathrm{mL}$, respectively, however, the minimum FPase and CMCase activity of 2.16 and $2.38 \mathrm{IU} / \mathrm{mL}$ was found at $\mathrm{pH} 4$ (Figure 7). A optimum $\mathrm{pH}$ is required to maintain the three dimensional shape of the active site of enzyme and the change in $\mathrm{pH}$ results in loss of functional shape of enzyme due to alteration in the ionic bonding of enzyme. 
For the production of cellulase by Bacillus subtilis and Bacillus circulans, the $\mathrm{pH}$ in the range of 7.0-7.5 was found to be optimum by Ray et al. [20]. The optimum $\mathrm{pH}$ for the maximum cellulase production was found to be 7.0 for cellulase production by Bacillus sp. 8 and Bacillus sp. 17 by Sohair et al. [16] also. The maximum CMCase activity of 0.29 $\mathrm{IU} / \mathrm{mL}$ was reported in a study on cellulase production by Bacillus $s p$. at $\mathrm{pH} 7$ [24].

\section{Effect of inoculum concentration}

The effect of different inoculum concentration i.e., $0.5 \%, 1 \%$, $2 \%, 3 \%, 4 \%$ (v/v) of Bacillus sp. Y3 culture on cellulase production was observed. The optimum inoculum concentration for cellulase production was recorded at $2 \%(\mathrm{v} / \mathrm{v})$ with maximum FPase and CMCase activity of 4.89 and $5.36 \mathrm{IU} / \mathrm{mL}$, respectively (Figure 8 ). After the optimal inoculum concentration, the enzyme activity was sharply reduced because microbial growth was decreased due to increase in competition for space and nutrients among cells. These factors also affect the length of stationary phase, which results in loss of enzyme activity due to accumulation of toxic products and secondary metabolites.

Similar results of maximum cellulase production at inoculum size of $2 \%(\mathrm{v} / \mathrm{v})$ were also reported by Acharya and Chaudhary [25]. The maximum FPase and CMCase activity of $0.338 \pm 0.021 \mathrm{IU} / \mathrm{mL}$ and $0.118 \pm 0.009 \mathrm{IU} / \mathrm{mL}$, respectively, was found in the media containing CMC from Bacillus licheniformis WBS1. In another study given by Shankar and Isaiarasu [23] on cellulase production by Bacillus pumilus, $2 \%(\mathrm{v} / \mathrm{v})$ inoculum size was found to be optimum for maximum cellulase production.

\section{Effect of incubation time}

The optimized media was incubated for different time intervals i.e., 24, 48, 72, 96, 120, 144, 168 hours after inoculating with Bacillus sp. Y3 to investigate the effect of incubation time on cellulase production. The optimum time for cellulase production with maximum FPase activity $(6.84 \mathrm{IU} / \mathrm{mL})$ and CMCase activity $(7.82 \mathrm{IU} / \mathrm{mL})$ was observed at 96 hours of incubation (Figure 9). The cellulase activity was significantly reduced after 96 hours due to depletion of nutrients or accumulation of other byproducts in the fermentation media which lead to decrease in cellulase activity [26].

The maximum cellulase production of $2.818 \mu \mathrm{g} / \mathrm{mg} / \mathrm{min}$ from thermophilic Bacillus sp. after 96 hours of incubation was also obtained by Das et al. [12].

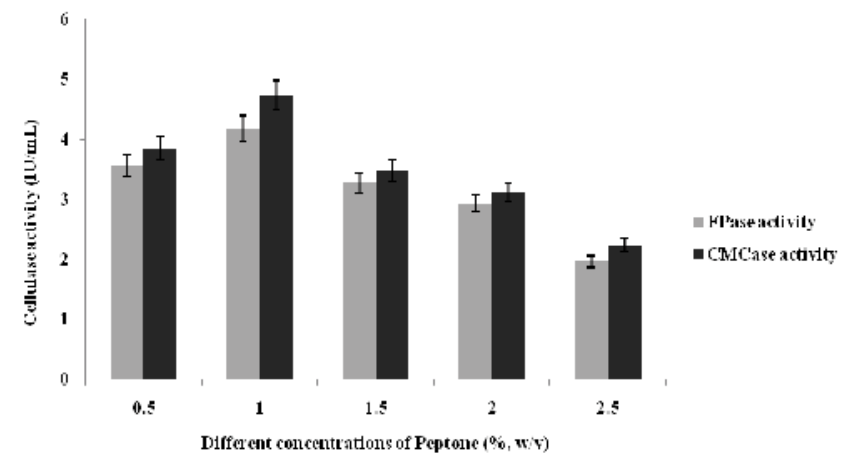

Figure 5: Effect of different concentrations of peptone on cellulase production by Bacillus sp. Y3.

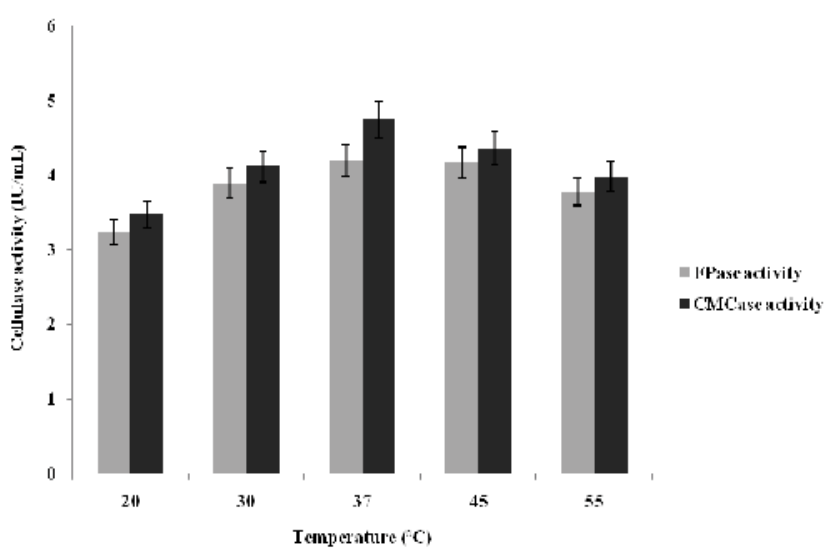

Figure 6: Effect of temperature on cellulase production by Bacillus $\mathrm{sp}$. Y3.

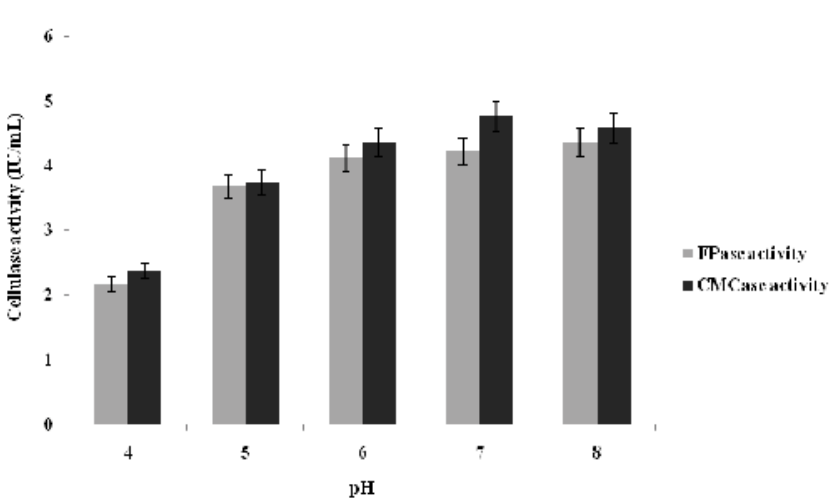

Figure 7: Effect of $\mathrm{pH}$ on cellulase production by Bacillus sp. Y3.

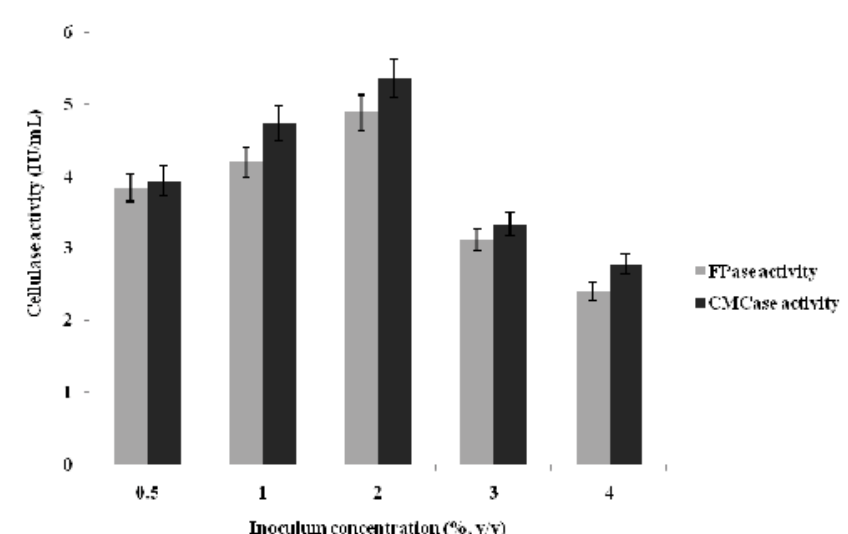

Figure 8: Effect of inoculum concentration on cellulase production by Bacillus sp. Y3.

\section{Conclusions}

This study provides the evidence for the production and optimization of cellulase production using Bacillus sp. Y3. The maximum cellulase production with FPase and CMCase activity of $6.84 \mathrm{IU} / \mathrm{mL}$ and 7.82 $\mathrm{IU} / \mathrm{mL}$, respectively, was found with Bacillus sp. Y3 in a basal media of $\mathrm{pH} 7$ containing CMC $(1 \%, \mathrm{w} / \mathrm{v})$ and peptone $(1 \%, \mathrm{w} / \mathrm{v})$ inoculated with $2 \%(\mathrm{v} / \mathrm{v})$ inoculum and incubated at $37^{\circ} \mathrm{C}$ for 96 hours at $120 \mathrm{rpm}$. The present study has proved that CMC and peptone are good carbon 


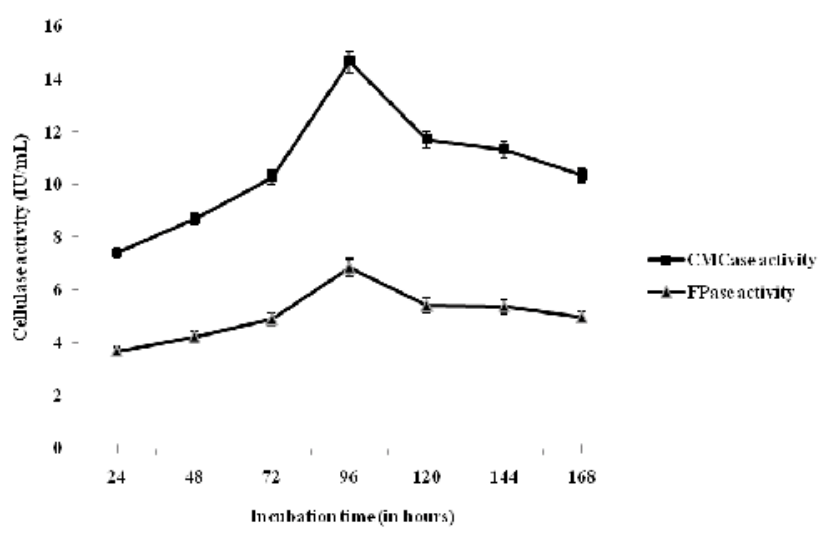

Figure 9: Effect of incubation time on cellulase production by Bacillus sp. Y3

and nitrogen source, respectively for maximum production of cellulase enzyme from Bacillus sp. Y3.

\section{Contributions}

The present study has been designed and conducted by Dr. Rajesh Singla and Ms. Yogita Lugani at Dolphin (PG) College of Life Science, Chunni Kalan. The manuscript is edited and proofread by Dr. Balwinder Singh Sooch at Punjabi University, Patiala.

\section{Acknowledgements}

We wish to extend our gratitude to Dolphin (PG) College of Life Sciences for providing us laboratory facilities required for this research work.

\section{References}

1. Lynd LR, Weimer PJ, van Zyl WH, Pretorius IS (2002) Microbial cellulose utilization: fundamentals and biotechnology. Microbiol Mol Biol Rev 66: 506577.

2. Bhat MK (2000) Cellulases and related enzymes in biotechnology. Biotechnol Adv 18: 355-383

3. Alani B, Zamani MR, Motallebi M, Zarghami (2005) Purification of polygalacturonase enzyme from strain F58 Fusarium oxysporum. August 28Sept 1 HUPO 4th Annual Word Congress, Munich.

4. Makky EA (2009) Avicelase production by a thermophilic Geobacillus stearothermophilus isolated from soil using sugarcane bagasse. World Acad Sci Eng Technol 39: 469-473.

5. Morales MAM, Hernandez JLM, Garza H, Aguilar CN (2011) Cellulolytic enzymes production by solid state culture using pecan nut shell as substrate and support. Am J Agri Biol Sci 62: 196-200.

6. Acharya A, Joshi DR, Shrestha K, Bhatta DR (2012) Isolation and screening of thermophilic cellulolytic bacteria from compost piles. Sci World 1010: 43-46.

7. Teather RM, Wood PJ (1982) Use of Congo red-polysaccharide interactions in enumeration and characterization of cellulolytic bacteria from the bovine rumen. Appl Environ Microbiol 43: 777-780.

8. Gram C (1884) Ueber die isolirte Firbung der Schizomyceten iu Schnitt-und Trockenpriparaten. Fortschr Med 2: 185-189.

9. Boone DR, Garrity GM, Castenholz RW, Brenner DJ, Krieg NR, et al. (2001) Genus Bacillus in Bergey's Manual of Systematic Bacteriology: The Firmicutes, Vol. 3. 2nd edn. Springer, New York, NY, USA. pp: 21-128.
10. Mandels M, Weber J (1969) The production of cellulases. In: Cellulases and their applications: A Symposium. GJ Hajny, ET Resse (ed.) American Chemical Society Advanced Series 95: 391-414.

11. Miller GL (1959) Use of dinitrosalicylic acid reagent for determination of reducing sugar. Anal Chem 31: 426-428.

12. Das A, Bhattacharya S, Murali L (2010) Production of cellulase from thermophilic Bacillus sp. isolated from cow dung. AM Eurasian J Agric Environ Sci 8: 685-691.

13. Ahmad B, Nigar S, Shah SSA, Bashir S, Ali J, et al. (2013) Isolation and identification of cellulose degrading bacteria from municipal waste and their screening for potential antimicrobial activity. World Appl Sci J 27: 1420-1426.

14. Rasul F, Afroz A, Rashid U, Mehmood S, Sughra K, et al. (2015) Screening and characterization of cellulase producing bacteria from soil and waste (molasses) of sugar industry. Int J Biosci 6: 230-238.

15. Gautam R, Sharma J (2012) Optimization, purification of cellulase produced from Bacillus subtilis subsp. inaquosorum under solid state fermentation and its potential applications in denim industry. Int J Sci Res 3: 1759-1763.

16. Nasr SA, Abozaid AA, Hussein NA, Al-Salemi FA (2011) Cellulase production by local bacteria isolated from Taif in Saudi Arabia. J Agri Sci 19: 163-170.

17. Sreedevi S, Sajith S, Benjamin S (2013) Cellulase producing bacteria from the wood-yards on kallai river bank. Adv Microbiol 3: 326-332.

18. Singh S, Moholkar VS, Goyal A (2014) Optimization of carboxymethylcellulase production from Bacillus amyloliquefaciens SS35. 3 Biotech 4: 411-424.

19. Ariffin H, Hassan MA, Shah UK, Abdullah N, Ghazali FM, et al. (2008) Production of bacterial endoglucanase from pretreated oil palm empty fruit bunch by Bacillus pumilus EB3. J Biosci Bioeng 106: 231-236.

20. Ray AK, Bairagi A, Ghosh KS, Sen SK (2007) Optimization of fermentation conditions for cellulase production by Bacillus subtilis CY5 and Bacillus circulans TP3 isolated from fish gut. Acta Ichthyologica ET Piscatoria 37: 47-53.

21. Bai S, Ravi Kumar M, Mukesh Kumar DJ, Balashanmugam $P$, Bala kumaran MD, et al. (2012) Cellulase production by Bacillus subtilis isolated from cow dung. Arch Appl Sci Res 4: 269 -279.

22. Paudel YP, Qin W (2015) Characterization of novel cellulase-producing bacteria isolated from rotting wood samples. Appl Biochem Biotechnol 177: 1186-1198.

23. Shankar T, Isaiarasu L (2011) Cellulase production by Bacillus pumilus EWBCM1 under varying cultural conditions. J Sci Res 8: 40-45.

24. Padilha QM, Carvalho LCT, Dias PVS, Grisi TCSL, da Silva FLH, et al. (2015) Production and characterization of thermophilic carboxymethyl cellulase synthesized by Bacillus sp. growing on sugarcane bagasse in submerged fermentation. Braz J Chem Eng 32: 35-42.

25. Acharya S, Chaudhary A (2011) Effect of nutritional and environmental factors on cellulases activity by thermophilic bacteria isolated from hot spring. J Sci Ind Res 70: 142-148.

26. Haq IU, Hameed U, Shahzadi K, Javed M, Ali S, et al. (2005) Cotton saccharifying activity of cellulases by Trichoderma harzianum UM-11 in shake flask. Int J Bot 1: 19-22. 